\title{
New genus of opecoelid trematode from Pristipomoides aquilonaris (Perciformes: Lutjanidae) and its phylogenetic affinity within the family Opecoelidae
}

\author{
Michael J. Andres, Eric E. Pulis and Robin M. Overstreet
}

Department of Coastal Sciences, University of Southern Mississippi, Ocean Springs, Mississippi, USA

\begin{abstract}
Bentholebouria colubrosa gen. n. et sp. n. (Digenea: Opecoelidae) is described in the wenchman, Pristipomoides aquilonaris (Goode et Bean), from the eastern Gulf of Mexico, and new combinations are proposed: Bentholebouria blatta (Bray et Justine, 2009) comb. n., Bentholebouria longisaccula (Yamaguti, 1970) comb. n., Bentholebouria rooseveltiae (Yamaguti, 1970) comb. n., and Bentholebouria ulaula (Yamaguti, 1970) comb. n. The new genus is morphologically similar to Neolebouria Gibson, 1976, but with a longer cirrus sac, entire testes, a rounded posterior margin with a cleft, and an apparent restriction to the deepwater snappers. Morphologically, the new species is closest to B. blatta from Pristipomoides argyrogrammicus (Valenciennes) off New Caledonia but can be differentiated by the nature of the internal seminal vesicle (2-6 turns or loops rather than constrictions), a longer internal seminal vesicle (occupying about $65 \%$ rather than $50 \%$ of the cirrus sac), a cirrus sac that extends further into the hindbody (averaging $136 \%$ rather than $103 \%$ of the distance from the posterior margin of the ventral sucker to the ovary), and a narrower body $(27 \%$ rather than $35 \%$ mean width as $\%$ of body length). A Bayesian inference analysis of partial sequence of the $28 \mathrm{~S}$ rDNA from Neolebouria lanceolata (Price, 1934), Cainocreadium lintoni (Siddiqi et Cable, 1960), Hamacreadium mutabile Linton, 1910 , Opecoeloides fimbriatus (Linton, 1910), Podocotyloides brevis Andres et Overstreet, 2013, the new species, and previously published comparable sequences from 10 opecoelid species revealed two clades. One clade includes deep-sea ( $\geq 200 \mathrm{~m})$ and freshwater fish opecoelids + Opecoeloides Bremser in Rudolphi, 1819, and a second clade included those opecoelids from shallow-water marine, perciform fishes.
\end{abstract}

Keywords: Digenea, molecular phylogeny, 28S rDNA, Neolebouria, Macvicaria, Hamacreadium, fishes, deep-sea

During a study on the helminths of marine fishes in the northern Gulf of Mexico, we detected an undescribed species of the family Opecoelidae Ozaki, 1925 infecting the intestinal tract of the wenchman, Pristipomoides aquilonaris (Goode et Bean). Using Cribb's (2005) key to the family, we keyed the species to the problematic genus Neolebouria Gibson, 1976. In particular, the new species was most similar to four other species of Neolebouria from the relatively deepwater snapper genera Pristipomoides Bleeker and Etelis Cuvier (Lutjanidae).

Neolebouria was erected for Neolebouria georgiensis Gibson, 1976 from the Antarctic fishes Parachaenichthys georgianus (Fischer) (Bathydraconidae) and Chaenocephalus aceratus (Lönnberg) (Channichthyidae) (see Gibson 1976). Gibson (1976) included Plagioporus-like worms containing an irregularly lobed ovary and vitelline fields confluent in the forebody in Neolebouria. Gibson and Bray (1982) amended the generic diagnosis to accommodate Neolebouria merretti Gibson et Bray, 1982, which has vitelline fields in the forebody that are not confluent. Zdzitowiecki (1990) considered Crassicutis antarcticus Szidat et Graefe, 1967 to be conspecific with $N$. georgiensis and proposed for it the new combination $N$. antarctica (Szidat et Graefe, 1967). Shimazu and Na- gasawa (1985) considered Neolebouria congeneric with Macvicaria Gibson et Bray, 1982, but Shimazu (1990) later accepted the genus. Morphologically, Neolebouria differs from Macvicaria primarily by having a lobed rather than an entire ovary. In Cribb's (2005) revision of the Opecoelidae, he retained Neolebouria but with the caveat that the distinction between the two genera may be artificial.

Bray and Justine (2009a) described Neolebouria blatta Bray et Justine, 2009 from the ornate jobfish, Pristipomoides argyrogrammicus (Valenciennes), and the ruby snapper, Etelis carbunculus Cuvier, off New Caledonia. In the same manuscript, they proposed two new combinations: one was for Plagioporus longisacculus Yamaguti, 1970 from the crimson jobfish, Pristipomoides filamentosus (Valenciennes) [as P. microlepis (Bleeker)], as Neolebouria longisacculus (Yamaguti, 1970), off Hawaii; the other was for Plagioporus rooseveltiae Yamaguti, 1970 from the oblique-banded snapper, Pristipomoides zonatus (Valenciennes) [as Rooseveltia brighami (Seale)], as Neolebouria rooseveltiae (Yamaguti, 1970) also off Hawaii. Bray and Justine (2009a) suggested that those three trematodes, along with another Hawaiian species, $\mathrm{Ne}$ olebouria ulaula (Yamaguti, 1970) (syn. Plagioporus ul- 
aula Yamaguti, 1970) from E. carbunculus [as E. marshi (Jenkins)], may form a monophyletic group as parasites of deepwater lutjanids and which is unrelated to the other nominal species of Neolebouria. They postulated that this potential group may be close to Hamacreadium Linton, 1910, for which $H$. mutabile Linton, 1910 is the type species. Hamacreadium includes members in shallow-water lutjanids and is morphologically similar to Neolebouria except that members have a longer excretory vesicle.

In addition to the species of Neolebouria mentioned above, Bray and Justine (2009b) recognized 20 other species from a variety of marine fishes, geographical locations and depths, including the 'deep-sea' for which we follow the designation by Bray (2004) as $\geq 200 \mathrm{~m}$. Two species of Neolebouria have been described from the subtropical western Atlantic Ocean: the deep-sea species Neolebouria lanceolata (Price, 1934) (as Podocotyle lanceolata Price, 1934) from the beardfish, Polymixia sp., off Puerto Rico in the Caribbean Sea and Neolebouria confusa (Overstreet, 1969) (as Hamacreadium confusum Overstreet, 1969) from the yellowtail snapper, Ocyurus chrysurus (Bloch). Reimer (1987) transferred P. lanceolata to Neolebouria based on its vitelline follicles extending into the forebody, and he provided additional measurements for specimens from the stout beardfish, Polymixia nobilis Lowe, off Mozambique. Cribb (2005) transferred H. confusum to Neolebouria, based on an excretory vesicle that only reaches the ovary rather than extending into the forebody as in Hamacreadium.

In the present study, we present a description of a new species and genus that is morphologically similar to $\mathrm{Ne}$ olebouria and use Bayesian inference (BI) analysis of partial 28S rDNA gene of the new species, $N$. lanceolata, Cainocreadium lintoni (Siddiqi et Cable, 1960), H. mutabile, Opecoeloides fimbriatus (Linton, 1910), Podocotyloides brevis Andres et Overstreet, 2013, and previously published sequences of 10 other opecoelids to estimate the phylogenetic position of the new species relative to Neolebouria, Hamacreadium, Macvicaria, and others in the family Opecoelidae.

\section{MATERIALS AND METHODS}

Specimens of the wenchman, Pristipomoides aquilonaris, the Atlantic croaker, Micropogonias undulatus (Linnaeus), the beardfish, Polymixia lowei (Günther), and the grey snapper, Lutjanus griseus (Linnaeus), were collected by trawl during the 2008, 2010-2012 National Marine Fisheries Service (NMFS) fall pelagic trawl surveys in the northern Gulf of Mexico. The grey conger, Conger esculentus (Poey), and the red grouper, Epinephelus morio (Valenciennes), were collected by longline (see Andres and Overstreet 2013) during the 2009 NMFS Caribbean survey. Fish were examined for trematodes aboard ship. Trematodes were washed briefly in a $0.8 \%$ saline solution, fixed with near-boiling tap water and placed in either $5 \%$ neutral buffered formalin solution or $70 \%$ molecular grade ethanol. Other specimens were placed at room-temperature in $95 \%$ molecular grade ethanol and refrigerated for later sequencing. Specimens were stained in Van Cleave's haematoxylin, aqueous Mayer's haematoxylin, followed by destaining in $1 \%$ sodium hydroxide solution, or water-based ammonium alum carmine solution.

Stained specimens were then dehydrated in a graded alcohol series. When specimens stained with Van Cleave's haematoxylin or carmine reached $80 \%$ ethanol, they were neutralized with one drop of lithium carbonate dissolved in $80 \%$ ethanol and two drops of a highly dilute butylamine solution. Dehydrated specimens stained with Van Cleave's or carmine solution were cleared in clove oil, specimens stained in Mayer's were cleared in methyl-salicylate and all were mounted in Canada balsam on glass slides. Measurements were made using a compound microscope equipped with a differential interference contrast, a Cannon EOS Rebel T1i camera, and calibrated digital software iSolutions Lite ${ }^{\circ}$. Measurements are presented as micrometres $(\mu \mathrm{m})$ and given for the holotype followed by a range of measurements from other specimens in parentheses. Illustrations were made with the aid of a drawing tube and digitally inked using a Wacom tablet (Wacom Co., Vancouver, Washington).

Genomic DNA was extracted from one hologenophore sensu Pleijel et al. (2008) and a second entire specimen of the new species and Neolebouria lanceolata, two entire specimens of Hamacredium mutabile, Opecoeloides fimbriatus and Podocotyloides brevis, and an entire single specimen of $C$. lintoni, using Qiagen DNAeasy Tissue Kit (Qiagen, Valencia, California, USA) and following the instructions provided. DNA fragments approximately 1100 basepairs (bp) long comprising the 5' end of the internal transcribed spacer region 2 (ITS2) nuclear rDNA gene and the 5 ' end of the $28 \mathrm{~S}$ gene (including variable domains D1-D3) were amplified from the extracted DNA by polymerase chain reaction (PCR) on a PTC-200 Peltier Thermal Cycler using forward primer LSU5 (5'-TAGGTCGACCCGCTGAAYTTAAGCA-3') and reverse primer 1500R (5'-GCTATCCTGAGGGAAACTTCG-3'). Sequencing reactions used the previous primers and the internal forward primers $300 \mathrm{~F}$ (5'-CAAGTACCGTGAGGGAAAGTTG-3') and 900F (5'-CCGTCTTGAAACACGGACCAAG-3') and internal reverse primer ECD2 (5'-CTTGGTCCGTGTTTCAAGACGGG-3').

The resulting PCR products obtained following the protocols of Tkach et al. (2003) were excised from PCR gel using QIAquick Gel Extraction Kit (Qiagen) following kit instructions, cycle-sequenced using ABI BigDye TM chemistry (Applied Biosystems, Carlsbad, California, USA), ethanol-precipitated, and run on an ABI 3130 Genetic AnalyzerTM. Contiguous sequences were assembled using SequencherTM (Version 4.10.1, GeneCodes Corp., Ann Arbor, Michigan, USA) and submitted to GenBank. Newly obtained sequences (Table 1) and sequences of opecoelids previously deposited in GenBank were used in the phylogenetic analysis.

Sequences obtained from GenBank are listed as follows: Cainocreadium labracis (Dujardin, 1845) (JQ694144) (Born-Torrijos et al. 2012), Gaevskajatrema halosauropsi Bray et Campbell, 1997 (AY222207) (Olson et al. 2003), Gaevskajatrema perezi (Mathias, 1926) (AF184255) (Tkach et al. 2001), Macvicaria macassarensis (Yamaguti, 1952) (AY222208) (Olson et al. 2003), Macvicaria mormyri (Stossich, 1885) (AF184256) (Tkach et al. 2001), Macvicaria obovata (Molin, 1859) (JQ694146) (BornTorrijos et al. 2012), Opecoeloides furcatus (Bremser in Rudolphi, 1819) (AF151937) (Tkach et al. 2000), Peracreadium idoneum (Nicoll, 1909) (AY222209) (Olson et al. 2003), Plagiocirrus loboides Curran, Overstreet et Tkach, 2007 (EF523477) (Curran 
Andres et al.: New opecoelid genus and its phylogenetic affinities

Table 1. Species of the Opecoelidae collected from the Gulf of Mexico and Caribbean Sea and their respective host species, GenBank accession number for the $28 \mathrm{~S}$, and deposition information.

\begin{tabular}{|c|c|c|c|c|c|c|}
\hline Species & Host & Year & Depth range $(\mathrm{m})$ & Coordinates & GenBank & USNPC \\
\hline Bentholebouria colubrosa & Pristipomoides aquilonaris & 2010,2012 & $138-163$ & $\begin{array}{l}26^{\circ} 58^{\prime} 38^{\prime \prime} \mathrm{N} \\
84^{\circ} 34^{\prime} 37^{\prime \prime} \mathrm{W}\end{array}$ & KJ001207 & 107969 \\
\hline Cainocreadium lintoni & Epinephelus morio & 2009 & 54 & $\begin{array}{l}18^{\circ} 25^{\prime} 27^{\prime \prime} \mathrm{N} \\
64^{\circ} 59^{\prime} 51^{\prime \prime} \mathrm{W}\end{array}$ & KJ001208 & 107970 \\
\hline Hamacreadium mutabile & Lutjanus griseus & 2010 & 57 & $\begin{array}{l}26^{\circ} 57^{\prime} 02^{\prime \prime} \mathrm{N} \\
83^{\circ} 45^{\prime} 45^{\prime \prime} \mathrm{W}\end{array}$ & KJ001209 & 107971 \\
\hline Neolebouria lanceolata & Polymixia lowei & 2008,2012 & $329-430$ & $\begin{array}{l}28^{\circ} 37^{\prime} 45^{\prime \prime} \mathrm{N} \\
86^{\circ} 05^{\prime} 48^{\prime \prime} \mathrm{W}\end{array}$ & KJ001210 & 107972 \\
\hline Opecoeloides fimbriatus & Micropogonias undulatus & 2011 & 53 & $\begin{array}{l}27^{\circ} 59^{\prime} 57^{\prime \prime} \mathrm{N} \\
95^{\circ} 34^{\prime} 06^{\prime \prime} \mathrm{W}\end{array}$ & KJ001211 & 107973 \\
\hline Podocotyloides brevis & Conger esculentus & 2009 & 200 & $\begin{array}{l}18^{\circ} 10^{\prime} 10^{\prime \prime} \mathrm{N} \\
67^{\circ} 26^{\prime} 29^{\prime \prime} \mathrm{W}\end{array}$ & KJ001212 & 106704 \\
\hline
\end{tabular}

et al. 2007), and Pseudopycnadena tendu Bray et Justine, 2007 (FJ788506) (Bray et al., 2009) (all Opecoelidae), plus Paragonimus kellicotti Ward, 1908 (HQ900670) (Fischer et al. 2011) and Paragonimus westermani (Kerbert, 1878) (AY116874) (Olson et al. 2003) (both Paragonimidae). The sequences were aligned initially using ClustalX 2.1 (Larkin et al. 2007) with the default setting and penalties (gap opening $=10$, gap extension $=0.02$, delay divergent sequences $=30 \%$, and DNA transition weight $=0.5$ ). The alignment was adjusted by eye in Bioedit, ver. 7.1.3.0. (Hall 1999) and trimmed to the shortest sequence on both $5^{\prime}$ and 3 ' ends.

The alignment included a total of 1167 sites after the trimming and removal of ambiguous regions, 765 of which were conserved. No intraspecific variation was found in cases when sequences were obtained from multiple individuals of each species. Phylogenetic analysis of the data was performed using Bayesian inference with MrBayes 3.1.2 software (Huelsenbeck and Ronquist 2001, Ronquist and Huelsenbeck 2003). The best nucleotide substitution model was estimated with jModeltest Version 0.1.1 (Posada 2008) as general time reversible with estimates of invariant sites and gamma-distributed among site-rate variation $(\mathrm{GTR}+\mathrm{I}+\Gamma)$. The following model parameters were used in MrBayes: nst $=6$, rates $=$ invgamma, ngen $=1,000,000$, and samplefreq $=100$. The first $25 \%$ of the samples were discarded as 'burnin' (sump burnin=2500), and nodal support was estimated by posterior probabilities (sumt) (Huelsenbeck and Ronquist 2001), with all other settings left as default. Paragonimus westermani was selected as the outgroup based on its phylogenetic position relative to the opecoelids (Olson et al. 2003).

\section{RESULTS}

\section{Bentholebouria gen. n.}

Figs. 1-4

Diagnosis. Opecoelidae. Body of adult slightly more than quarter of length, flattened subcylindrical, more tapered anteriorly than posteriorly, with posterior margin having cleft. Oral sucker subterminal, without ornamentation. Ventral sucker approximately at or near level of anterior third of body, larger than oral sucker. Prepharynx indistinct to short. Pharynx subglobular to globular, smaller than oral sucker. Oesophagus present. Intestinal bifurcation approximately at mid-forebody. Caeca ending blindly. Testes 2, oblique. Cirrus sac elongate clavi- form, extending into hindbody or to posterior margin of ventral sucker. Genital pore at level of or just anterior to intestinal bifurcation, sinistrally submedian. Ovary lobed (3-9 lobes), anterodextral to anterior testes. Seminal receptacle canalicular. Uterus intercaecal. Vitellarium follicular, extending into forebody, circumcaecal, confluent in post-testicular region. Excretory vesicle I-shaped, passes mediodorsal to testes to level of ovary. Excetory pore at base of posterior cleft. In intestine of relatively deepwater lutjanids, known from Pristipomoides and Etelis.

Type species: Bentholebouria colubrosa sp. n.

Et y mology: The Greek Bentho for 'deep' refers to the hosts Pristipomoides and Etelis, commonly called the deepwater snappers. We treat Bentholebouria as feminine because the initial generic name Lebouria was apparently named after the late marine biologist Marie V. Lebour.

Remarks. Of marine plagioporine genera that have all or some members with a lobed ovary and unfilamented eggs, the new genus is morphologically most similar to Neolebouria, Cainocreadium Nicoll, 1909, Hamacreadium and Podocotyle Dujardin, 1845. It can be distinguished from most members of Neolebouria by having a combination of a cirrus sac that extends at least to the posterior margin of the ventral sucker, entire testes, a rounded posterior margin with a cleft, and an apparent restriction to the deepwater snapper genera Pristipomoides and Etelis.

Bentholebouria can be distinguished from Cainocreadium by having a submedian genital pore that is at the level of, or just anterior to, the intestinal bifurcation rather than a median, post-bifurcal genital pore. Bentholebouria is similar to Hamacreadium but has a longer cirrus sac and an excretory vesicle that extends only to the level of the ovary rather than into the forebody. Podocotyle is a 'taxonomic mine-field' (Gibson and Bray 1982), but its members usually have a trilobed ovary, tandem testes and vitelline fields that are restricted to the hindbody or just enter the forebody.

\section{Bentholebouria colubrosa sp. $\mathrm{n}$.}

Figs. 1-4

Description (based on 16 mature measured wholemounts): Body orangish-pink in life, elongate spatulate, $2.7 \mathrm{~mm}$ (1.9-2.7 mm) long, 683 (545-759) wide at mid- 

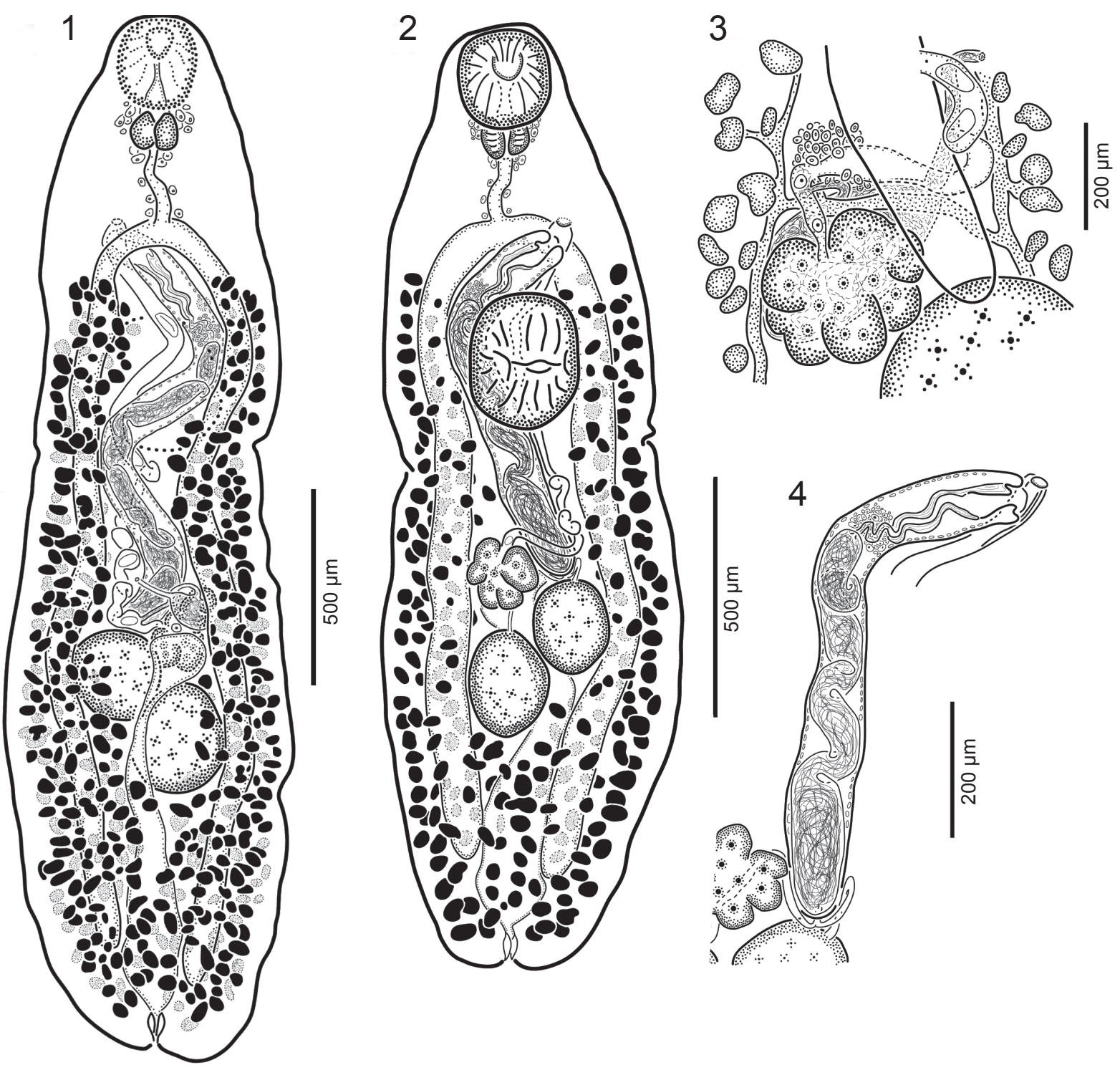

Fig. 1-4. Bentholebouria colubrosa gen. et sp. n. from Pristipomoides aquilonaris. Fig. 1. Dorsal view, holotype. Fig. 2. Ventral view, paratype. Fig. 3. Ventral view, female complex, dark 'U' shape outline of posterior end of cirrus sac. Fig. 4. Ventral view, terminal genitalia.

body, $25.3 \%(21.1-28.4 \%)$ of body length (BL), with lateral margins of hindbody irregular to smooth. Tegument thin. Oral sucker globular, 224 (171-224) long, 198 (141-208) wide. Preoral lobe absent to distinct. Ventral sucker subglobular, 349 (268-353) long, 310 (221-342) wide. Ratio of oral sucker to ventral sucker width $1: 1.6$ (1: 1.3-2.0). Forebody 738 (516-738) long, representing 27\% (24-29\%) of BL. Prepharynx 9 (7-23) long. Pharynx subglobular, 96 (68-101) long, 119 (91-119) wide. Oesophagus approximately as long as oral sucker, slightly sigmoid, bifurcating approximately 187 (125-187) from anterior end of ventral sucker; caeca terminating 176 (110-244) from posterior end of body. Gland cells associated with lateral margins of pharynx and oesophagus.
Testes oblique, oval, smooth, nearly contiguous, near mid-hindbody; anterior testis 233 (173-246) long, 231 (152-234) wide; posterior testis 272 (213-272) long, 217 (163-217) wide. Post-testicular space 666 (519-699), representing approximately $25 \%(25-28 \%)$ of BL. Cirrus sac (CS) 1277 (873-1277) long, representing 47\% $(41-56 \%)$ of BL, 80 (73-95) wide at widest point posteriorly, extending to level of middle to anterior of ovary, slightly sigmoid, with gland cells along periphery. Vasa efferentia uniting vas deferens at proximal end of CS. Internal seminal vesicle elongate, occupying approximately $68 \%$ (59-69\%) of CS, wider proximally, with 2-6 loops or turns, occasionally with constrictions. Pars prostatica short, separated from seminal vesicle by sphincter. Ejaculatory duct thick-walled, 295 (178-295) long, occupying 


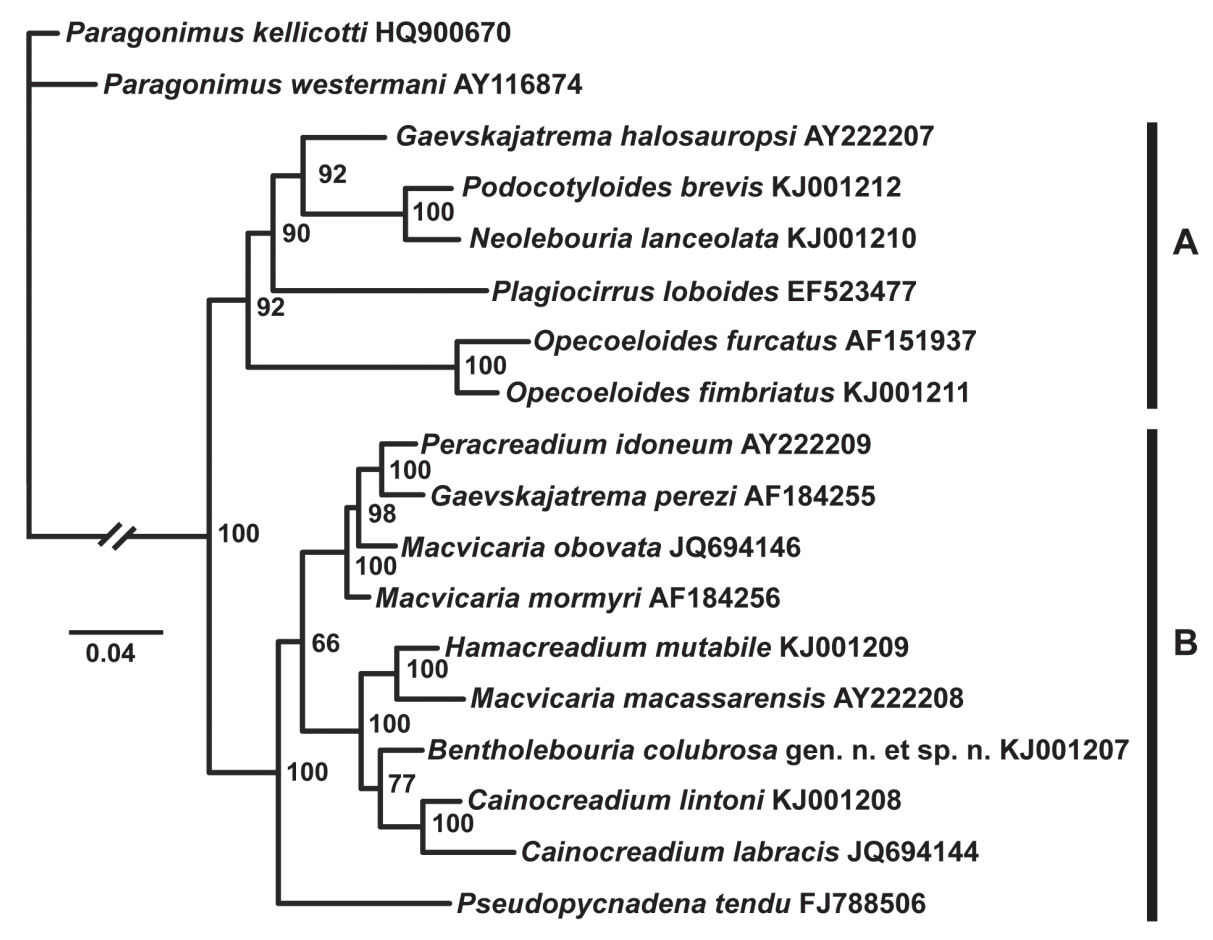

Fig. 5. Phylogenetic relationships among members of the Opecoelidae resulting from Bayesian inference analysis of partial sequences of 28S rDNA gene (GTR $+\mathrm{I}+\Gamma, 1000000$ generations and a sample frequency of 100) and producing a monophyletic opecoelids with two major clades ('A' and 'B').

$23 \%(20-25 \%)$ of CS, unspined, may be pocketed. Genital atrium $28(20-42)$ long.

Ovary 201 (71-231) long, 125 (75-213) wide, with 4 (4-7) lobes, slightly separate from to contiguous with dextral margin of anterior testis, ventral to CS. Laurer's canal containing seminal receptacle, opening dorsally; seminal receptacle approximately same size as ovary, oval, dorsal to ovary. Mehlis' gland anterodorsal to ovary. Uterus pretesticular, intercaecal, with walls of metraterm not significantly thickened. Eggs operculate, 62 (50-72) long, 34 (32-41) wide. Vitellarium comprised of 2 lateral fields of small follicles; fields extending from level 92 (11-122) anterior to ventral sucker, lateral groups dorsal and ventral to testes, circumcaecal, confluent in posttesticular region.

Excretory vesicle I-shaped, wider posteriorly, narrows anteriorly, extends dorsomedially to level of ovary; pore at base of posterior cleft, with globular sphincter.

Type host: Pristipomoides aquilonaris (Goode et Bean), wenchman, Lutjanidae.

Site: Intestine.

Type locality: Gulf of Mexico, West Florida Shelf, approximately $230 \mathrm{~km}$ south east of Tampa Bay, Florida, $26^{\circ} 29^{\prime} 46^{\prime \prime} \mathrm{N}, 84^{\circ} 30^{\prime} 10^{\prime \prime} \mathrm{W}$, at $138 \mathrm{~m}$ depth.

Other localities: Gulf of Mexico, West Florida Shelf; $26^{\circ} 58^{\prime} 38^{\prime \prime} \mathrm{N}, 84^{\circ} 34^{\prime} 37^{\prime \prime} \mathrm{W}$, at $163 \mathrm{~m}$ depth; $26^{\circ} 7^{\prime} 57^{\prime \prime} \mathrm{N}$, $84^{\circ} 06^{\prime} 13^{\prime \prime}$, at $153 \mathrm{~m}$ depth.

Infections: 10 worms from 5 pooled fish (2010, type locality); 3, 0, 0, 0, 0, and 0 worms from 6 fish $(2012,163 \mathrm{~m}$ depth); 4, 1, and 1 worms from 3 fish (2012, $153 \mathrm{~m} \mathrm{depth).}$ Specimens deposited: United States National Parasite Museum Collection (USNPC), Beltsville, MD, USA, holotype (USNPC 107967); paratypes in the British Museum of Natural History London, England (2014.3.13.1), and Institute of Parasitology, Biology Centre of the Academy of Sciences of the Czech Republic, České Budějovice, Czech Republic (IPCAS D-699).

Etymology: The Latin, adjectival, feminine name colubrosa refers to the winding, turning, looping nature of the seminal vesicle.

Remarks. Bentholebouria colubrosa sp. n. is chosen as the type species because it is coupled with molecular data. Bray and Justine (2009a) suggested that the deepwater snappers (primarily Pristipomoides) likely hosted a monophyletic clade of opecoelids that share similar morphological features and life-histories. We agree with them and propose the combinations Bentholebouria blatta (Bray et Justine, 2009) comb. n., Bentholebouria longisaccula (Yamaguti, 1970) comb. n., Bentholebouria rooseveltiae (Yamaguti, 1970) comb. n., and Bentholebouria ulaula (Yamaguti, 1970) comb. n. for species from deepwater lutjanids previously attributed to Neolebouria.

Morphologically, B. colubrosa is most similar to $B$. blatta but can be distinguished by having an internal seminal vesicle that has two to six turns and loops rather than one that is elongated, occasionally with several constrictions and without turns or loops. Additionally, the new species has a longer internal seminal vesicle (occu- 
pying approximately $65 \%$ rather than approximately $50 \%$ of the ciruss sac), a ciruss sac that extends further into the hindbody (averaging 136\% rather than 103\% of the distance from the posterior margin of the ventral sucker to the ovary), and a narrower body (27\% rather than $35 \%$ of the mean width as $\%$ body length). Compared with the Hawaiian species, B. colubrosa is most similar to B. rooseveltiae, but that species has an elongate and saccular internal seminal vesicle and a cirrus sac that extends to the level of the posterior end of the ventral sucker. The new species can be differentiated from the other four species of Bentholebouria based on geography, with the new species being located in the Gulf of Mexico off Florida, whereas B. blatta occurs off New Caledonia (Bray and Justine 2009) and the other three species off Hawaii (Yamaguti 1970). In 2012, we did not find the new species in 36 specimens of $P$. aquilonaris sampled from nine stations north of $27^{\circ} \mathrm{N}$, but we did find it in 4 of 10 hosts from three stations south of $27^{\circ} \mathrm{N}$.

Molecular analysis. The Bayesian inference analysis of partial 28S rDNA gene sequences showed the monophyly of the Opecoelidae and revealed two major clades, 'A' and 'B' (Fig. 5). The two major plus most subclades were characterized by high posterior probability values. Clade 'A' included opecoelids that infect Atlantic and Gulf of Mexico deep-sea fishes (Gaevskajatrema halosauropsi, Neolebouria lanceolata and Podocotyloides brevis), Nearctic freshwater fish (Plagiocirrus loboides), and both species of the opecoeline genus Opecoeloides Odhner, 1928. Clade ' $\mathrm{B}$ ' includes members that primarily infect shallow-water marine fishes in the perciform suborders Percoidea and Labroidei (Bentholebouria colubrosa, both species of Cainocreadium, Gaevskajatrema perezi, Hamacreadium mutabile, the three species of Macvicaria, Peracreadium idoneum and Pseudopycnadena tendu. The analysis also revealed that Macvicaria and Gaevskajatrema Gibson et Bray, 1982 are polyphyletic.

\section{DISCUSSION}

We erected Bentholebouria because our phylogenetic analysis agrees with the suggestion by Bray and Justine (2009a) that the opecoelids from the deepwater snappers likely form a monophyletic clade; the new species and Neolebouria lanceolata were resolved in two different clades. Consequently, we have combined four species formerly in Neolebouria that share morphological and ecological similarities with the new species in Bentholebouria. Following the key to Neolebouria by Bray and Justine (2009b), we could also included Neolebouria georgenascimentoi Bray, 2002 infecting the rollizo sandperch, Pinguipes chilensis Valenciennes, and the tilefish, Prolatilus jugularis (Valenciennes) (both Pinguipedidae), off Chile based on the entire testes and a cirrus sac that extends posterior to or overlaps with the ovary, but we chose not to include $N$. georgenascimentoi, a species with interrupted vitelline fields, in the new genus based on the lack of sequence data, host differences and some morphological differences such as a tapered posterior margin rather than being rounded with a cleft at the excretory pore.

We retain $N$. lanceolata in Neolebouria, even though the phylogenetic status of Neolebouria is still unresolved until the type species, $N$. antarctica, is sequenced, and its affinity to $N$. lanceolata can be confirmed. The frequent finding of deep-sea fish trematodes of the family Lepidapedidae Yamaguti, 1958 (sensu Bray and Cribb 2012) in fishes from Antarctic continental-shelf fishes may indicate that some members of that family are also adapted for cold waters (Bray et al. 1999, 2009, Bray 2004). This adaptation suggests that $N$. lanceolata, with its bathydemersal hosts (Polymixia spp.), belongs in $\mathrm{Ne}$ olebouria. Physical and environmental conditions along the Antarctic Shelf may facilitate deep-sea invertebrate faunas around the Antarctic being related to both adjacent shelf communities and to those in other oceans (e.g. Gage 2004, Brandt et al. 2007). If so, perhaps the intermediate hosts of $N$. antarctica and $N$. lanceolata are phylogenetically closer to each other than to those of shallow-water intermediate hosts.

Recent studies on the opecoelids (Jousson et al. 2000, Jousson and Bartoli 2001) and other groups (see Poulin 2011) have revealed that morphologically similar species occurring in different hosts (Curran et al. 2013) or in different geographical locations (Miller and Cribb 2007, Detwiler et al. 2010) are sometimes cryptic species. Our specimens identified as $N$. lanceolata are similar to those reported by both Price (1934) and Reimer (1987), but future workers should use sequence data to compare specimens from the Indian Ocean with those of this study to see if $N$. lanceolata reported by Reimer (1987) actually represents a cryptic species. This comparison would be particularly useful because the host and basin are different. If $N$. lanceolata does not represent a species complex, host-parasite systems in the deep-sea would seem to follow the same pattern exhibited by free-living deepsea organisms, i.e. genetic divergence is much greater between populations at different depths than with those separated geographically at the same depth (see Etter et al. 2011). Manter (1966) suggested the same pattern for the cold-water adapted derogenid Derogenes varius (Müller, 1784), which is a common shallow-water parasite of fishes at higher latitudes and probably has a continuous, world-wide distribution in deeper waters. Since $N$. antarctica has been reported from three families of demersal Antarctic fish (Bathydraconidae, Channichthyidae, Nototheniidae) (Zdzitowiecki 1988, 1990, 1991), it may be a complex of species.

Bray and Justine (2009a) suggested that the four species we now consider in Bentholebouria may be close to Hamacreadium, based on similar host preference (lutjanids) and morphological features. We determined that B. colubrosa was in a subclade with Hamacreadium but more closely related to Cainocreadium, though only with 
moderate support. Hamacreadium mutabile was closest to Macvicaria macassarensis from the trumpet emperor, Lethrinus miniatus (Forster) (Lethrinidae), forming a subclade sister to B. colubrosa + Cainocreadium.

Neolebouria has been suggested to have a close relationship with Macvicaria by Shimazu and Nagasawa (1985) and Shimazu (1990). We were unable to investigate this hypothesis because the three species of Macvicaria used in our analysis fell out in two different positions in the shallow-water host clade. Therefore, the phylogenetic position of Macvicaria remains speculative, and the relationship of Macvicaria to the rest of the members of clade ' $\mathrm{B}$ ' in the present analysis is inconclusive.

Gaevskajatrema was also represented in both of our major clades, G. halosauropsi in clade 'A' and G. perezi in clade ' $\mathrm{B}$ '. Of the three deep-sea species in our phylogeny, $G$. halosauropsi is from the greatest depth $(2570 \mathrm{~m}$; see Bray and Campbell 1996) and is sister to the two slopespecies, Podocotyloides brevis and Neolebouria lanceolata. Bray and Campbell (1996) described G. halosauropsi from Halosauropsis macrochir (Günther) and amended the generic diagnosis of Gaevskajatrema to include forms with a lobed ovary. Gaevskajatrema perezi is the type species of the genus and is known from labrids in shallow waters of the NE Atlantic (Gibson and Bray 1982) and Mediterranean (Jousson et al. 1999). Thus, Gaevskajatrema (sensu stricto) probably includes shallow-water forms with an entire ovary, short caeca and vitelline follicles that do not extend beyond the testes, and are likely from perciform fishes.

Plagiocirrus loboides was the only freshwater species used in this analysis, and it was sister to the three deep-sea forms. In the phylogenetic analysis by Curran et al. (2007), P. loboides was closest to O. furcatus, which led the authors to suggest that the relationships among genera in the Plagioporinae Manter, 1947 needs to be reevaluated. We agree with Curran et al. (2007), since we found both species of Opecoeloides were sister to each other and were resolved in clade 'A'. However, all but the two species of Opecoeloides (Opecoelinae Ozaki, 1925) used in our Bayesian inference analysis are plagioporines sensu Cribb (2005); thus, the grouping of Opecoeloides in clade 'A' could be an artifact of under-sampling. Including members of Opecoelus Ozaki, 1925 and Plagioporus Stafford, 1904 and members of the two other subfamilies, the Stenakrinae Yamaguti, 1970 and the Opecoelininae Gibson et Bray, 1984, should clarify the relationships within the family, especially within clade ' $A$ '.

Our analysis was the first molecular intrafamilial phylogenetic one for the opecoelids that included more than four species. Most molecular approaches that have used opecoelids have focused on elucidating life cycles (Jousson et al. 1999, Born-Torrijos et al. 2012), cryptic species determination (Jousson et al. 2000, Jousson and Bartoli 2001), part of broad phylogenetic studies (Tkach et al. 2000, 2001, Olson et al. 2003, Bray et al 2009), or the placement of a genus of uncertain status (Curran et al. 2007). We have provided sequences that help access the relationships among some plagioporines, but the large family still requires a more comprehensive treatment so that the extent to which convergence occurs in several large morphological genera such as Helicometra Odhner, 1808, Macvicaria, Neolebouria, Podocotyle and Podocotyloides Yamaguti, 1934 can be determined.

Acknowledgements. We thank the National Marine Fisheries Service Laboratory in Pascagoula, Mississippi, for making sampling possible and continuing a productive collaboration. We are especially grateful to Dr. William Driggers III, Dr. Christopher Gledhill, Marc Grace, Alonzo Hamilton, Michael Hendon, Nick Hopkins, Dr. Walter Ingram, Lisa Jones, Adam Pollack, Kevin Rademacher, and the crew of the NOAA ships Gordon Gunter, Oregon II, and Pisces. We thank Pat Pilitt, USNPC, for examining and photographing specimens and for providing accession numbers. From the University of Southern Mississippi we thank Jean Jovonvich-Alvillar and Dr. Janet Wright for their assistance with DNA sequencing reactions and Dr. Stephen Curran for help with sampling, a review of an early version of the manuscript and advice. The material treated here is based on work supported by the National Science Foundation under grant No. 0529684, Ocean and Human Health Initiative grant No. NA08NOS4730322, and US Fish and Wildlife Service/Mississippi Department of Marine Resources MSCIAP MS.R.798 Award M10AF20151.

\section{REFERENCES}

Andres M.J., Overstreet R.M. 2013: A new species of Podocotyloides (Digenea: Opecoelidae) from the grey conger eel, Conger esculentus, in the Caribbean Sea. J. Parasitol. 99: 619-623.

Born-Torrijos A., Kostadinova A., Raga J.A., Holzer A.S. 2012: Molecular and morphological identification of larval opecoelids (Digenea: Opecoelidae) parasitizing prosobranch snails in a Western Mediterranean lagoon. Parasitol. Int. 61: $450-460$

Brandt A., Gooday A.J., Brandẽo S.N., Brix S., Brökeland W., Cenhagen T., Choudhury M., Cornelius N., Danis B., De Mesel I., Diaz R.J., Gillan D.C., Ebbe B., Howe J.A., Janussen D., Kaiser S., Linse K., Malyutina M., PawLOWSKi J., Raupach M., Vanreusel A. 2007: First insights into the biodiversity and biogeography of the Southern Ocean deep sea. Nature 447: 307-311.

BRAY R.A. 2004: The bathymetric distribution of the digenean parasites of deep-sea fishes. Folia Parasitol. 51: 268-274.

Bray R.A., Campbell R.A. 1996: New plagioporines (Digenea: Opecoelidae) from deep-sea fishes of the Northern Atlantic Ocean. Syst. Parasitol. 33: 101-113.

Bray R.A., CribB T.H. 2012: Reorganisation of the superfamily Lepocreadioidea Odhner, 1905 based on an inferred molecular phylogeny. Syst. Parasitol. 83: 169-177.

Bray R.A., Justine J.-L. 2009a: Neolebouria blatta n. sp. (Digenea: Opecoelidae) from Pristipomoides argyrogrammicus 
(Valenciennes) and Etelis carbunculus Cuvier (Perciformes: Lutjanidae) off New Caledonia. Syst. Parasitol. 74: 161-167.

Bray R.A., Justine J.-L. 2009b: Opecoelids (Platyhelminthes, Digenea) from the fork-tailed threadfin bream Nemipterus furcosus (Valenciennes, 1830) (Perciformes, Nemipteridae), with preliminary keys to the problematic genera Macvicaria Gibson et Bray, 1982 and Neolebouria Gibson, 1976. Acta Parasitol. 54: $218-229$.

Bray R.A., Littlewood D.T.J., Herniou E.A., Williams B., Henderson R.E. 1999: Digenean parasites of deep-sea teleosts: a review and case studies of intrageneric phylogenies. Parasitology 119: S125-S144.

Bray R.A., Waeschenbach A., Cribb T.H., Weedall G.D., Dyal P., LitTlewood D.T.J. 2009: The phylogeny of the Lepocreadioidea (Platyhelminthes, Digenea) inferred from nuclear and mitochondrial genes: implications for their systematics and evolution. Acta Parasitol. 54: 310-329.

Cribi T.H. 2005: Family Opecoelidae Ozaki, 1925. In: A. Jones, R.A. Bray and D.I. Gibson (Eds.), Keys to the Trematoda. Volume 2. CABI Publishing and the Natural History Museum, London, pp. 443-539.

Curran S.S., Overstreet R.M., Tkach V.V. 2007: Phylogenetic affinities of Plagiocirrus Van Cleave and Mueller, 1932 with the description of a new species from the Pascagoula River, Mississippi. J. Parasitol. 93: 1452-1458.

Curran S.S., TKach V.V., Overstreet R.M. 2013: A new species of Homalometron (Digenea: Apocreadiidae) from fishes in the northern Gulf of Mexico. J. Parasitol. 99: 93-101.

Detwiler J.T., Bos D.H., Minchella D.J. 2010: Revealing the secret lives of cryptic species: examining the phylogenetic relationships of echinostome parasites in North America. Mol. Phylogenet. Evol. 55: 611-620.

Etter R.J., Boyle E.E., Glazier A., Jennings R.M., Dutra E., Chase M.R. 2011: Phylogeography of a pan-Atlantic abyssal protobranch bivalve: implications for evolution in the Deep Atlantic. Mol. Ecol. 20: 829-843.

Fischer P.U., Curtis K.C., Marcos L.A., Weil G.J. 2011: Molecular characterization of the North American lung fluke Paragonimus kellicotti in Missouri and its development in Mongolian gerbils. Am. J. Trop. Med. Hyg. 84: 1005-1011.

GAGE J.D. 2004: Diversity in deep-sea benthic macrofauna: the importance of local ecology, the larger scale, history and the Antarctic. Deep-Sea Res. II 51: 1689-1708.

Gibson D.I. 1976: Monogenea and Digenea from fishes. Discovery Rep. 36: 179-266.

Gibson D.I., Bray R.A. 1982: A study and reorganization of Plagioporus Stafford, 1904 (Digenea: Opecoelidae) and related genera, with special reference to forms from European Atlantic waters. J. Nat. Hist. 16: 529-559.

Hall T.A. 1999: BioEdit: a user-friendly biological sequence alignment editor and analysis program for Windows 95/98/NT. Nucl. Acids Res. 41: 95-98.

Huelsenbeck J. P., Ronquist F. 2001: MRBAYES: Bayesian inference of phylogeny. Bioinformatics 17: 754-755.

Jousson O., Bartoli P. 2001: Molecules, morphology and morphometrics of Cainocreadium labracis and Cainocreadium dentecis n. sp. (Digenea: Opecoelidae) parasitic in marine fishes. Int. J. Parasitol. 31: 706-714.

Jousson O., Bartoli P., Pawlowski J. 1999: Molecular identification of developmental stages in Opecoelidae (Digenea). Int. J. Parasitol. 29: 1853-1858.

Jousson O., Bartoli P., Pawlowski J. 2000: Cryptic speciation among intestinal parasites (Trematoda: Digenea) infecting sympatric host fishes (Sparidae). J. Evol. Biol. 13: 778-785.
Larkin M.A., Blackshields G., Brown N.P., Chenna R., McGettigan P.A., McWilliam H., Valentin F., Wallace I.M., Wilm A., Lopez R., Thompson J.D., Gibson T.J., Higgins D.G. 2007: Clustal W and Clustal X version 2.0. Bioinfromatics 23: 2947-2948.

Manter H.W. 1966: Parasites of fishes as biological indicators of recent and ancient conditions. In: J.E. McCauley (Ed.), HostParasite Relationships. Oregon State University Press, Corvallis, Oregon, pp. 59-71.

Miller T.L., CRibB T.H. 2007: Two new cryptogonimid genera (Digenea, Cryptogonimidae) from Lutjanus bohar (Perciformes, Lutjanidae): analyses of ribosomal DNA reveals wide geographic distribution and presence of cryptic species. Acta Parasitol. 52: 104-113.

Olson P.D., Cribi T.H., Tkach V.V., Bray R.A., Littlewood D.T.J. 2003: Phylogeny and classification of the Digenea (Platyhelminthes: Trematoda). Int. J. Parasitol. 33: 733-755.

Pleijel F., Jondelius U., Norlinder E., Nygren A., Oxelman B., Schander C., Sundberg P., Thollesson M. 2008: Phylogenies without roots? A plea for the use of vouchers in molecular phylogenetic studies. Mol. Phylogenet. Evol. 48: 369-371.

Posada D. 2008: jModelTest: phylogenetic model averaging. Mol. Biol. Evol. 25: 1253-1256.

Poulin R. 2011: Uneven distribution of cryptic diversity among higher taxa of parasitic worms. Biol. Lett. 7: 241-244.

Price E.W. 1934: New digenetic trematodes from marine fishes. Smithson. Misc. Collect. 91: 1-8.

Reimer L.W. 1987: Opecoelidae (Trematoda) von Meeresfischen vor Moçambique. Angew. Parasitol. 28: 148-158.

Ronquist F., Huelsenbeck J. P. 2003: MRBAYES 3: Bayesian phylogenetic inference under mixed models. Bioinformatics 19: $1572-1574$.

Shimazu T. 1990: Trematodes of a new genus, Neoplagioporus gen. n. (Digenea: Opecoelidae: Plagioporinae), and an unidentified opecoelid from freshwater fishes of Japan. Jpn. J. Parasitol. 39: 384-396.

Shimazu T., Nagasawa K. 1985: Trematodes of marine fishes from Moroiso Bay, Misaki, Kanagawa Prefecture, Japan. J. Nagano-ken Junior College 40: 7-15.

Tkach V.V., Littlewood D.T.J., Olson P.D., Kinsella J.N., Swiderski Z. 2003: Molecular phylogenetic analysis of the Microphalloidea Ward, 1901 (Trematoda: Digenea). Syst. Parasitol. 56: 1-15.

Tkach V.V., Pawlowski J., Mariaux, J. 2000: Phylogenetic analysis of the suborder Plagiorchiata (Platyhelminthes, Digenea) based on partial lsrDNA sequences. Int. J. Parsitol. 30: 83-93.

Tkach V.V., Pawlowski J., Mariaux J., Swiderski Z. 2001: Molecular phylogeny of the suborder Plagiorchiata and its position in the system of Digenea. In: D.T.J. Littlewood and R.A. Bray (Eds.), Interrelationships of the Platyhelminthes. Taylor and Francis, London, pp. 186-193.

Yamaguti S. 1970: Digenetic trematodes of Hawaiian fishes. Keigaku, Tokyo, pp. 436.

Zdzitowiecki K. 1988: Occurrence of digenetic trematodes in fishes off South Shetlands (Antarctic). Acta Parasitol. Pol. 33: $155-167$

ZdZitowiecki K. 1990: Reexamination of five Antarctic and subantarctic digenean and acanthocephalan species from Professor Szidat's collection. Acta Parasitol. Pol. 35: 31-36.

ZDZITOWIECKI K. 1991: Occurrence of digeneans in open sea fishes off the South Shetland Islands and South Georgia, and a list of fish digeneans in the Antarctic. Pol. Polar Res. 12: 55-72. 